\title{
Determinants of Children's Nutritional Status in Malawi
}

Lemekezani K. Chilora and Jan Duchoslav

This Working Paper is an output of the Bunda Grant Scheme program of IFPRI-Lilongwe. This mentorship scheme provides selected MSc students from the Lilongwe University of Agriculture and Natural Resources (Bunda College) with opportunities to improve, publish, and disseminate the research that they undertake during their MSc training by working with a seasoned researcher from IFPRI. The Bunda Grant Scheme program is made possible by the support of the American people through the United States Agency for International Development (USAID). The views expressed in this working paper imply no endorsement by IFPRI-Malawi, USAID, or anyone except the authors. 


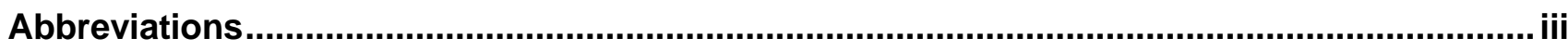

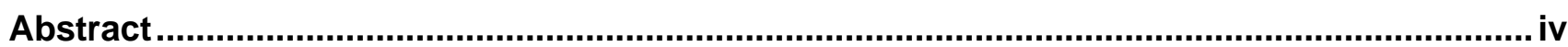

1. Introduction .............................................................................................................

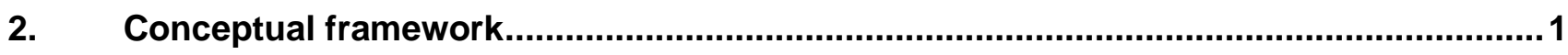

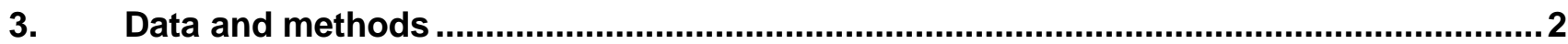

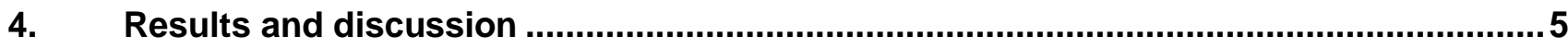

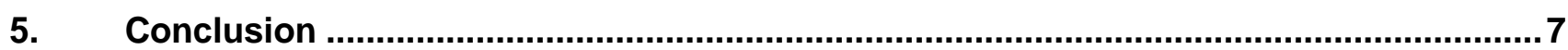

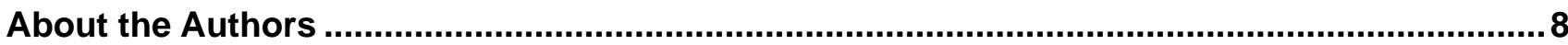

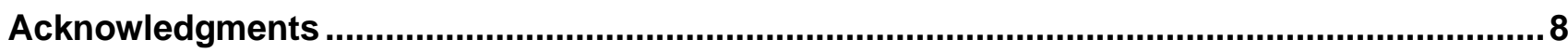

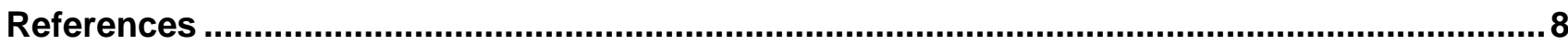

Annex

\section{TABLES}

Table 1. Children under five per household ................................................................................

Table 2. Descriptive statistics (outcome variables) ........................................................................

Table 3. Descriptive statistics (independent variables) ....................................................................

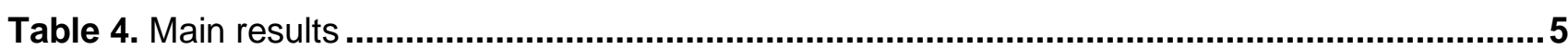

Table A 1. Independent variables .........................................................................................10

Table A 2. Robustness checks (weight-for-height) …..................................................................11

Table A 3. Robustness checks (height-for-age) .......................................................................13 


\section{ABBREVIATIONS}

$\begin{array}{ll}\text { HAZ } & \text { height-for-weight z-score } \\ \text { HDDS } & \text { Household Dietary Diversity Score } \\ \text { IHS } & \text { Integrated Household Survey } \\ \text { NSO } & \text { National Statistical Office of Malawi } \\ \text { OLS } & \text { Ordinary Least Squares } \\ \text { WAZ } & \text { weight-for-age z-score } \\ \text { WHZ } & \text { weight-for-height z-score }\end{array}$




\section{ABSTRACT}

Malnutrition reduction efforts can be targeted based on the characteristics that affect children's nutritional status. Using data from a nationally representative survey, we model the determinants of young children's nutritional status in Malawi as measured by height-for-age and weight-for-height zscores. We identify several determinants of children's nutritional status including their gender (boys are more malnourished than girls), their mother's education, the food security and location of their household (rural children are more acutely but not chronically malnourished than urban children) and access to clean water.

Key words: malnutrition, nutritional status, height-for age, weight-for-height, Malawi 


\section{INTRODUCTION}

Despite some long-term global improvements in nutrition, the number of malnourished children has risen in recent years, especially in Africa as well as in West Asia and Latin America (Development Initiatives 2020). Malnutrition during gestation and early childhood has negative consequences lasting into adulthood: early-life malnutrition hinders later-life cognitive abilities (Berkman et al. 2002), educational attainment (Chang et al. 2002), health (Barker 1990) and lifetime earnings (Black, Devereux, Salvanes 2007; Bharadwaj, Lundborg, Rooth 2018). Where prevalent, these individual setbacks in aggregate hamper economic development at the national level (WHO 2017).

With high levels of child malnutrition, Malawi suffers gravely from its various consequences. Several studies have investigated the sources of malnutrition in the country, but the evidence is geographically limited (Sassi 2014) or based on old data (Maganga and Maganga 2018) and so far, inconclusive. Using the latest available nationally representative survey data to investigate the determinants of the nutritional status of under-five children in Malawi, the present paper fills this literature gap and is organized as follows: Section 2 outlines the conceptual framework of the study, section 3 describes the data and the methodology used to analyze it, section 4 presents and discusses the results and section 5 concludes.

\section{CONCEPTUAL FRAMEWORK}

A child's nutritional status is commonly measured using three anthropometric indices: weight-forheight, height-for-age, and weight-for-age. Weight-for-height compares a child's height to the typical weight of healthy children of the same height and sex. It is defined as a z-score (WHZ), calculated by subtracting from the child's weight a height- and sex-appropriate median value from a healthy population, and dividing the difference by the standard deviation of that population. It is a proxy for the child's nutritional status at the time of measurement, and its low values thus indicate acute malnutrition. A typical healthy child has $\mathrm{WHZ}$ of zero. A child whose $\mathrm{WHZ}$ is lower than -2 is considered wasted.

Similarly, height-for-age compares a child's height to the typical height of healthy children of the same age and sex. It is also defined as a z-score (HAZ) calculated using a standard population of an appropriate age and sex. It is a cumulative measure of a child's nutritional status, with low values indicating chronic malnutrition. A typical healthy child has HAZ of zero. A child whose HAZ is lower than -2 is considered stunted.

Weight-for-age compares a child's weight to the typical weight of healthy children of the same age and sex and is again defined as a z-score (WAZ) calculated using a standard healthy population. Being effectively a composite measure of weight-for-height and height-for-age, weight-for-age does not have a direct interpretation and is therefore not used in this paper.

Makombe et al. (2010) demonstrated that there is a strong association between household characteristics and food security and nutritional status. Gross et al. (2000) showed that there is a correlation between individual and household characteristics and food consumption. Strauss and Thomas (1998) provided evidence that there is also a relationship between an individual's nutritional status and environmental characteristics. Therefore, we propose a relationship between individual, household, environmental characteristics, and under-five child nutrition.

We expect individual child characteristics, especially gender, to affect nutritional outcomes. Although boys tend to be culturally preferred to girls, they have been shown to suffer from worse nutritional outcomes (Linnemayr, Alderman, Ka 2008). 
Household characteristics are also expected to influence children's nutritional outcomes. Maganga and Maganga (2018) found that households in urban areas in Malawi were more likely to have malnourished children than those in rural areas, arguing that this is due to poor dietary quality rather than quantity. Other studies have shown that children living in rural areas are likely to have poor nutritional status due to high poverty levels (Kruger, Pretorius, Schutte 2010).

Based on the results of previous studies (Maganga and Maganga 2018; Betebo et al. 2017), we expect household size to have a negative effect on under-five nutrition, as land rather than labor tends to be the constraining factor of food production in Malawi.

Due to their inexperience in childcare, children of young mothers tend to be less well nourished than children of relatively older mothers (Linnemayr, Alderman, Ka 2008). Since it is not possible to determine the age of the children's mother from the IHS data, we instead hypothesize that the age of the household head is positively correlated with the age of the mother, and therefore with nutritional outcomes. For similar reason, we also expect children of educated mothers to have better nutritional outcomes than children of uneducated mothers.

Nutritional quantity and quality should naturally also affect nutritional outcomes. We expect children from food secure households to have higher WHZ and HAZ than children from food insecure households (Betebo et al. 2017; Wolfe and Frongillo 2001; Coates et al. 2006) and the number of daily meals typically eaten by children to positively affect their nutritional status. We further expect household per capita energy intake, animal protein intake and dietary diversity to be positively correlated with children's nutritional status (Mwaniki and Makokha 2013; Braun et al. 2016; Owolabi et al. 1996; Michalsen and Greer 2014; Hatløy, Torheim, Oshaug 1998; Ogle, Hung, Tuyet 2001; Torheim et al. 2003).

Good sanitation improves health by preventing the spread of infectious diseases, which would otherwise prevent individuals from fully processing the nutrients they consume (Maganga and Maganga 2018). We therefore expect access to a safe water source and a toilet to improve children's nutritional status. Similarly, we expect the utilization of health services such as under-five clinics and nutrition programs to improve children's nutritional status (Kansiime et al. 2017; Webb and Rogers 2003).

\section{DATA AND METHODS}

The study used the fourth Integrated Household Survey (IHS4) data collected in 2016-2017 by the National Statistics Office (NSO) in Malawi. The IHS4 is a multi-discipline survey, which collected data using household, agriculture, aquaculture, and community questionnaires. The household questionnaire collected data on household characteristics (socio-economic and demographic), child anthropometric measurements and safety net programs. It collected information from a sample of 12,447 rural households statistically planned to be representative at district and rural/urban levels after application of correct sampling weights. 5,244 of these households had one or more children under the age of five for whom weight-for-height or height-for-age could be calculated, ${ }^{1}$ making for a total sample of 6,296 children (Table 1). Data from this sample was analyzed using STATA 16 and the zanthro (Vidmar, Cole, Pan 2016) and zscore06 (Leroy 2011) programs for anthropometric analysis. $^{2}$

\footnotetext{
${ }^{1}$ Height/length is missing for 10 children from 6 families.

${ }^{2}$ zanthro can compute WHZ only for heights in excess of $65 \mathrm{~cm}$, whereas zscore 06 can compute WHZ only for heights below $110 \mathrm{~cm}$. On common support, they the WHZ score they produce are correlated at 0.9998 . We use WHZ values produced by zanthro where possible and substitute them with values produced by zscore 06 for children shorter than $65 \mathrm{~cm}$. HAZ values produced by the two programs are identical.
} 


\begin{tabular}{lrr}
$\mathbf{1}$ & 4,258 & 4,258 \\
$\mathbf{2}$ & 926 & 1,852 \\
$\mathbf{3}$ & 56 & 168 \\
$\mathbf{4}$ & 2 & 8 \\
$\mathbf{5}$ & 2 & 10 \\
Total & 5,244 & 6,296 \\
\hline
\end{tabular}

Note: Authors' calculations based on IHS4 data.

The two outcome variables used to measure children's nutritional status - a weight-for-height zscore (WHZ) for acute malnutrition and a height-for-age z-score (HAZ) for chronic malnutrition - are expressed as a number of standard deviation from a standard population mean (WHO 2006). With a mean of -0.102 and -1.137 respectively, the children in our sample are clearly less well-nourished than children in a standard population. With WHZ and HAZ lower than -2 indicating wasting (i.e. acute malnutrition) and stunting (i.e. chronic malnutrition) respectively, 6.8 percent of children in our sample are wasted and 28.9 percent are stunted (Table 2).

Table 2. Descriptive statistics (outcome variables)

\begin{tabular}{lccccc} 
Variable & Mean & Std. dev & Min & Max $^{\text {Obs. }}{ }^{3}$ \\
\hline Weight-for-height (WHZ) & -0.101 & 1.272 & -4.986 & 4.958 & 6,278 \\
Height-for-age (HAZ) & -1.147 & 1.147 & -4.991 & 3.673 & 6,281 \\
Wasted & 0.068 & 0.251 & 0 & 1 & 6,278 \\
Stunted & 0.289 & 0.454 & 0 & 1 & 6,281 \\
\hline
\end{tabular}

Note: Authors' calculations based on IHS4 data.

Table 3 presents a summary of the descriptive statistics of explanatory variables used in the study (see Table A 1 in the Annex for their precise definitions). The average child is 2 years and 9 months old and 51.3 percent are girls. 16.6 percent reside in urban areas in households with an average size of 5.2 members. 24.1 percent live in female-headed households, and the average household head age is 36.1 years. Only a minority of children's mothers finished primary education (22.8 percent).

77.2 percent of children live in food insecure households. However, most households still manage to consume a relatively calorie-rich and diverse diet with a median daily per capita energy consumption of $1,906 \mathrm{kcal}$ and a median Household Dietary Diversity Score (HDDS) of 8, although most households did not consume any animal protein in the week prior to their interview. Children aged between 6 months and 5 years typically ate three meals a day while adults ate just two.

\footnotetext{
${ }^{3}$ Following common practice, we consider values more than 5 standard deviations from the standard population mean to be unrealistic (as a result of measurement and/or data entry errors). 7 observations had HWZ>5 and 6 observations had WHZ<-5. Additionally, 5 observations had weight and height values outside the WHO growth charts, preventing calculation of WHZ scores for them. Excluding these 18 observations reduces the sample size in estimations that include WHZ to 6,278. Separately, 15 observations had HAZ<-5, which reduces the sample size in estimations that include HAZ to 6,281. Including the observations with extreme WHZ and HAZ values in the estimations does not significantly alter the results (see model 2 in Table A 2 and model 2 in Table A 3 in the Annex).
} 
87.3 percent of children in the sample lived in households with access to clean water and 90.9 percent had access to a toilet. 7.9 percent of children in the sample lived in households that participated in an under-five nutrition program in the year prior to the interview, and 75.2 percent of the children attended under-five clinics.

Table 3. Descriptive statistics (independent variables)

\begin{tabular}{|c|c|c|c|c|c|c|}
\hline Variable & Mean & Std. dev. & Min. & Med. & Max. & Obs. \\
\hline \multicolumn{7}{|c|}{ Child characteristics } \\
\hline Female & 0.513 & 0.500 & 0 & & 1 & 6,296 \\
\hline Age (years) & 2.730 & 1.283 & 0.083 & 2.750 & 4.917 & 6,296 \\
\hline
\end{tabular}

\section{Household characteristics}

\begin{tabular}{|c|c|c|c|c|c|c|}
\hline Urban & 0.166 & 0.372 & 0 & & 1 & 6,296 \\
\hline Size & 5.201 & 1.866 & 2 & 5 & 17 & 6,296 \\
\hline Female head & 0.241 & 0.428 & 0 & & 1 & 6,296 \\
\hline Head age (years) & 36.081 & 11.341 & 16 & 34 & 94 & 6,296 \\
\hline Educated mother & 0.228 & 0.419 & 0 & & 1 & 6,296 \\
\hline
\end{tabular}

\section{Nutrition}

\begin{tabular}{|c|c|c|c|c|c|c|}
\hline Low food security & 0.772 & 0.419 & 0 & & 1 & 6,295 \\
\hline Household dietary diversity score (HDDS) & 7.832 & 2.304 & 3 & 8 & 12 & 6,296 \\
\hline Energy intake ${ }^{4}$ ('000 kcal/person/day) & 2.055 & 0.944 & 0.042 & 1.906 & 7.000 & 6,296 \\
\hline Protein intake (g/person/day) & 3.624 & 6.640 & 0 & 0 & 99.283 & 6,296 \\
\hline Adult meals per day & 2.420 & 0.589 & 0 & 2 & 4 & 6,296 \\
\hline Under-five meals per day ${ }^{5}$ & 2.701 & 0.877 & 0 & 3 & 9 & 5,973 \\
\hline \multicolumn{7}{|l|}{ Sanitation } \\
\hline Clean water & 0.873 & 0.333 & 0 & & 1 & 6,296 \\
\hline Toilet & 0.909 & 0.288 & 0 & & 1 & 6,296 \\
\hline \multicolumn{7}{|l|}{ Use of health services } \\
\hline Under-five nutrition program & 0.079 & 0.269 & 0 & & 1 & 6,296 \\
\hline Under-five clinic & 0.752 & 0.432 & 0 & & 1 & 6,296 \\
\hline
\end{tabular}

Note: Authors' calculations based on IHS4 data.

\footnotetext{
${ }^{4}$ We consider daily per capita energy intake in excess of 7,000 kcal unrealistic (this being energy intake at the level of a top-flight sumo wrestler) and censor energy intake values at that value.

5 The number of daily meals typically consumed by children aged between 6 months and 5 years is a problematic variable in IHS4: It is not reported for 284 households which have a child between 6 month and 5 years of age, but it is reported for 2,245 households without a child in that age range. We therefore consider this variable to be unreliable and do not include it in our main estimations, choosing to proxy for it by the number of meals consumed by adults in the household. Using the number of under-five meals with a reduced sample does not significantly alter the results (see model 3 in Table A 2 and model 3 in Table A 3 in the Annex).
} 
We employ the ordinary least squares (OLS) method to determine and quantify the relationship between children's nutritional status and the explanatory variables described above by fitting the following model:

$$
Y_{i}=\alpha+\boldsymbol{\beta}^{\prime} \boldsymbol{X}_{\boldsymbol{i}}+\varepsilon_{i}
$$

where $\mathrm{Yi}$ is the value of the outcome variable ( $\mathrm{WHZ}$ or $\mathrm{HAZ}$ ) of child $\mathrm{i}, \mathrm{X}$ is a vector of explanatory variable and $\beta$ a vector of their estimated coefficients. $\alpha$ is a constant term and $\varepsilon$ a stochastic error term.

\section{RESULTS AND DISCUSSION}

Table 4 presents the OLS parameter estimates of the factors influencing children's weight-for-height $\mathrm{z}$-score (WHZ) as a measure of acute malnutrition and height-for-weight z-score (HAZ) as a measure of chronic malnutrition.

\section{Table 4. Main results}

\begin{tabular}{|c|c|c|}
\hline Dependent variable & $\begin{array}{c}(1) \\
W H Z\end{array}$ & $\begin{array}{l}(2) \\
\text { HAZ }\end{array}$ \\
\hline \multicolumn{3}{|l|}{ Child characteristics } \\
\hline \multirow[t]{2}{*}{ Female } & $0.108^{* * *}$ & $0.122^{* * *}$ \\
\hline & $(0.037)$ & $(0.041)$ \\
\hline \multirow[t]{2}{*}{ Age } & $0.097^{* \star \star}$ & $-0.254^{* * *}$ \\
\hline & $(0.016)$ & $(0.017)$ \\
\hline
\end{tabular}

\section{Household characteristics}

\begin{tabular}{|c|c|c|}
\hline \multirow[t]{2}{*}{ Urban } & $0.170^{* * *}$ & 0.012 \\
\hline & $(0.064)$ & $(0.077)$ \\
\hline \multirow[t]{2}{*}{ Size } & 0.002 & 0.015 \\
\hline & $(0.012)$ & $(0.015)$ \\
\hline \multirow[t]{2}{*}{ Female head } & 0.042 & 0.020 \\
\hline & $(0.054)$ & $(0.058)$ \\
\hline \multirow[t]{2}{*}{ Head age } & 0.001 & $0.004^{*}$ \\
\hline & $(0.002)$ & $(0.002)$ \\
\hline \multirow[t]{2}{*}{ Educated mother } & 0.080 & $0.196^{* * *}$ \\
\hline & $(0.053)$ & $(0.054)$ \\
\hline \multicolumn{3}{|l|}{ Nutrition } \\
\hline \multirow[t]{2}{*}{ Low food security } & 0.044 & $-0.202^{* * *}$ \\
\hline & $(0.057)$ & $(0.062)$ \\
\hline \multirow[t]{2}{*}{ Household dietary diversity score (HDDS) } & -0.004 & $-0.030^{* *}$ \\
\hline & $(0.015)$ & $(0.013)$ \\
\hline \multirow[t]{2}{*}{ Energy intake ('000 kcal/person/day) } & 0.030 & 0.003 \\
\hline & $(0.024)$ & $(0.032)$ \\
\hline
\end{tabular}




\begin{tabular}{|c|c|c|}
\hline Dependent variable & $\begin{array}{c}(1) \\
\text { WHz }\end{array}$ & $\stackrel{\text { (2) }}{H A Z}$ \\
\hline \multirow[t]{2}{*}{ Protein intake (g/person/day) } & 0.005 & 0.000 \\
\hline & $(0.003)$ & $(0.004)$ \\
\hline \multirow[t]{2}{*}{ Adult meals per day } & 0.052 & 0.020 \\
\hline & $(0.049)$ & $(0.040)$ \\
\hline \multicolumn{3}{|l|}{ Sanitation } \\
\hline \multirow[t]{2}{*}{ Clean water } & -0.006 & $0.172^{*+*}$ \\
\hline & $(0.054)$ & $(0.064)$ \\
\hline \multirow[t]{2}{*}{ Toilet } & 0.038 & 0.041 \\
\hline & $(0.067)$ & $(0.067)$ \\
\hline \multicolumn{3}{|l|}{ Use of health services } \\
\hline \multirow[t]{2}{*}{ Under-five nutrition program } & $-0.197^{* *}$ & -0.103 \\
\hline & $(0.074)$ & $(0.076)$ \\
\hline \multirow[t]{2}{*}{ Under-five clinic } & 0.075 & $-0.212^{* *}$ \\
\hline & $(0.053)$ & $(0.055)$ \\
\hline Observations & 6,277 & 6,280 \\
\hline $\mathbf{R}^{2}$ & 0.021 & 0.065 \\
\hline
\end{tabular}

Note: Authors' estimations based on IHS4 data. Standard errors in parentheses; ${ }^{*} p<0.10,{ }^{, *} p<0.05,{ }^{* * *} p<0.01$.

We find that girls have around 0.11 standard deviation higher $\mathrm{WHZ}$ and $\mathrm{HAZ}$, i.e. are less acutely and chronically malnourished than boys, which is consistent with existing literature (Linnemayr, Alderman, Ka 2008). Older children are less likely to be acutely malnourished but more likely to be chronically malnourished.

Children in urban households are less acutely malnourished than children in rural households, but there is no meaningful difference between children in urban and rural households when it comes to chronic malnutrition. This suggests that the quality of nutrition in rural households is less stable than in urban households, but their average long-run nutritional quality is similar. Indeed, including the month of interview in the estimation (see model 4 in Table A 2 in the Annex) to account for seasonality reduces the magnitude of the effect of residence location on $\mathrm{WHZ}$.

Interestingly, other household demographics such as household size and the sex and age of the household head make little meaningful difference to under-five nutritional status, both immediate and long-term. The level of education of the child's mother also does not impact acute malnutrition in a statistically significant way, but it has an effect on chronic malnutrition: Children whose mothers completed primary education have higher HAZ, i.e. they are less chronically malnourished, than children of uneducated mothers. The relationship between acute malnutrition and mother's education is, however, statistically insignificant. Assuming that educated mothers are better informed about health and nutrition issues, this suggest that they may not be able to prevent short term nutritional shortfalls but are better able to mitigate their cumulative effects on their children than uneducated mothers.

Similarly, household food security status has a large and significant effect on chronic malnutrition but not on acute malnutrition, even though its measure is based on a one-week recall period. 
Chronic malnutrition is also affected by dietary diversity as measured by the HDDS, but curiously, dietary diversity is negatively correlated with HAZ, i.e. chronically malnourished children live in households with higher dietary diversity. However, this may be a reaction to their malnutrition rather than its cause as parents attempt to improve their diet, or a secondary effect of food insecurity as households diversify their consumption to include less preferred foods such as fruit in place of maize (Gelli et al. 2020).

Household per capita energy intake, per capita animal protein intake and the number of meals typically consumed by adult household members do not affect under-five nutritional status at all. Because individual energy and protein intake should have a strong impact on both immediate and cumulative nutritional status, the lack of detectable impact of their average per capita measures suggests that the way available food is distributed to individuals within a household differs across households.

Access to a clean water source also improves children's long-term nutritional outcomes as measured by HAZ but not immediate outcomes measured by WHZ. Access to a toilet seems to have no effect on children's nutritional status.

Children living in households who participate in under-five nutrition programs have lower WHZ than other children, and children who attend an under-five clinic have lower HAZ than other children. These relationships are contrary to the influence that such programs should have on children's nutrition, which suggests that the services are used in reaction to children's poor nutritional status, not that such programs have a negative impact on it.

Overall, the estimated relationship between the outcome variables and their determinants is robust to re-specifying the models as linear probability of binary variables indicating wasting and stunting (see model 5 in Table A 2 and model 4 in Table A 3 in the Annex). However, it is evident from the low $R^{2}$ values on all estimated models that the nutrition determinants investigated here explain only a small part in the variation of the nutritional status of under-five children.

\section{CONCLUSION}

We model the factors associating with the nutritional status of under-five children in Malawi by conducting an empirical analysis using IHS4 data, with weight-for-height and height-for-age z-scores (WHZ and HAZ) standing in for acute and chronic nutritional status and a number of socio-economic and environmental factors as potential determinants of these outcomes.

We find that girls have on average better nutritional status than boys, both in the short term (WHZ) and in the long term (HAZ). Children in urban households suffer from less acute malnutrition than their rural counterparts, but this positive effect does not translate into lower levels of chronic malnutrition. Mother's education, access to clean water and food security positively affect children's height-for-age but not their weight-for-height.

These relationships are robust, but only explain a small part of the variation in children's nutritional status. A dedicated dataset with a wider range of potential determinants would be needed to investigate the sources of under-five malnutrition in Malawi further. 


\section{ABOUT THE AUTHORS}

Lemekezani K. Chilora is a MSc student in the Department of Agricultural and Applied Economics at the Lilongwe University of Agriculture and Natural Resources (LUANAR).

Jan Duchoslav is a Research Fellow in the Development Strategy and Governance Division (DSGD) of IFPRI and leading IFPRI Malawi's research theme on "Social Safety Nets and Breaking the Humanitarian Cycle."

\section{ACKNOWLEDGMENTS}

This Working Paper is an output of the Bunda Grant Scheme program of IFPRI-Lilongwe. This mentorship scheme provides selected MSc students from the Lilongwe University of Agriculture and Natural Resources (Bunda College) with opportunities to improve, publish, and disseminate the research that they undertake during their MSc training by working with a seasoned researcher from IFPRI. The Bunda Grant Scheme program is made possible by the generous support of the American people through the United States Agency for International Development (USAID). The views expressed in this working paper imply no endorsement by IFPRI-Malawi, USAID, or anyone except the authors. The authors would like to thank Sandra Froebe for editorial and formatting assistance.

\section{REFERENCES}

Barker, D. J. 1990. "The Fetal and Infant Origins of Adult Disease." British Medical Journal 301 (1111) https://doi.org/10.1136/bmj.301.6761.1111

Berkman, D. S., A. G. Lescano, R. H. Gilman, S. L. Lopez, and M. M. Black. 2002. "Effects of Stunting, Diarrhoeal Disease, and Parasitic Infection during Infancy on Cognition in Late Childhood: A Follow-up Study." The Lancet 359: 564-571. https://doi.org/10.1016/S0140-6736(02)07744-9

Betebo, B., T. Ejajo, F. Alemseged, and D. Massa. 2017. "Household Food Insecurity and Its Association with Nutritional Status of Children 6-59 Months of Age in East Badawacho District, South Ethiopia." Journal of Environmental and Public Health 2017. https://doi.org/10.1155/2017/6373595

Bharadwaj, P., P. Lundborg, and D.-O. Rooth. 2018. "Birth Weight in the Long Run." Journal of Human Resources 53 (1): $189-231$. https://doi.org/10.3368/ihr.53.1.0715-7235R

Black, S. E., P. J. Devereux, and K. G. Salvanes. 2007. "From the Cradle to the Labor Market? The Effect of Birth Weight on Adult Outcomes. Quarterly Journal of Economics 122 (1): 409-439. https://doi.org/10.1162/qiec.122.1.409

Braun, K. VE., N. S. Erler, J. C. Kiefte-de Joung, V. W, Jaddoe, E. H. van den Hooven, O. H. Franco, and T. Voortman. 2016. "Dietary Intake of Protein in Early Childhood is Associated with Growth Trajectories between 1 and 9 Years of Age." Journal of Nutrition 146 (11): 2361-2367. DOI: 10.3945/jn.116.237164

Chang, S. M., S. P. Walker, S. Grantham-McGregor, and C. A. Powell. 2002. "Early Childhood Stunting and Later Behaviour and School Achievement." Journal of Child Psychology and Psychiatry 43 (6): 775-783. https://doi.org/10.1111/1469-7610.00088

Coates J., E. A. Frongillo, B. L. Rogers, P. Webb, P. E. Wilde, and R. Houser. 2006. "Commonalities in the Experience of Household Food Insecurity across Cultures: What Are Measures Missing?"Journal of Nutrition 136 (5):1438S-1448S. https://doi.org/10.1093/jin/136.5.1438S

Development Initiatives. 2020. Global Nutrition Report 2020: Action on Equity to End Malnutrition. Bristol, UK.

Gelli, A., J. Donovan, A. Margolies, N. Aberman, M. Santacroce, E. Chirwa, S. Henson, and C. Hawkes. 2020. "Value Chains to Improve Diets: Diagnostics to Support Intervention Design in Malawi." Global Food Security 25: 1-10. https://doi.org/10.1016/i.gfs.2019.09.006

Gross, R., H. Schoeneberger, H. Pfeifer, and H.-J. A. Preuss. 2000. The Four Dimensions of Food and Nutrition Security: Definitions and Concepts. European Union; InWEnt; Food and Agriculture Organization of the United Nations.

Hatløy A, LE. Torheim, and A. Oshaug. 1998. "Food Variety-A Good Indicator of Nutritional Adequacy of the Diet? A Case Study from an Urban Area in Mali, West Africa." European Journal of Clinical Nutrition 52: 891-898.

Kansiime, N., D. Atwine, S. Nuwamanya, and F. Bagenda. 2017. "Effect of Male Involvement on the Nutritional Status of Children Less Than 5 Years: A Cross Sectional Study in a Rural Southwestern District of Uganda." Journal of Nutrition and Metabolism 2017 : 1-9. https://doi.org/10.1155/2017/3427087

Kruger, H. S., R. Pretorius, and A. E. Schutte. 2010. "Stunting, Adiposity and Low-grade Inflammation in African Adolescents from a Township High School. Nutrition 26 (1): 90-99. https://doi.org/10.1016/i.nut.2009.10.004

Leroy, J. L. 2011. ZSCORE06: Stata module to calculate anthropometric z-scores using the 2006 WHO child growth standards. Statistical Software Components S457279. Boston, MA: College Department of Economics. 
Linnemayr, S., H. Alderman, and A. Ka. 2008. "Determinants of Malnutrition in Senegal: Individual, Household, Community Variables and their Interaction." Economics \& Human Biology 6 (2): 252-263. https://doi.org/10.1016/i.ehb.2008.04.003

Maganga, M. and A. Maganga. 2018. "Determinants of Nutrition Outcomes in Under-five Children: Experiences from Malawi." Paper presented at the international conference of Agricultural Economists, Vancouver, British Columbia, July 28-August 2. 10.22004/ag.econ.277347

Makombe, T., P. Lewin, and M. Fisher. 2010. The Determinants of Food Security in Rural Malawi. MaSSP Policy Note 4. Lilongwe: Malawi. International Food Policy Research Institute.

Michalsen, K. F. and F. R. Greer. 2014. "Protein Needs Early in Life and Long-term Health. American Journal or Clinical Nutrition 99 (3): 718S-722S. https://doi.org/10.3945/ajcn.113.072603

Mwaniki, E. W. and A. N. Makokha. 2013. "Nutrition Status and Associated Factors Among Children in Public Primary Schools in Dagoretti, Nairobi, Kenya. African Health Sciences 13 (1): 39-46. DOI: 10.4314/ahs.v13i1.6

Ogle, B. M., P. H. Hung, and H. T. Tuyet. 2001. "Significance of Wild Vegetables in Micronutrient Intakes of Women in Vietnam: An Analysis of Food Variety. Asia Pacific Journal of Clinical Nutrition 10 (1):21-30. https://doi.org/10.1046/j.1440-6047.2001.00206.X

Owolabi, A. O., J. O. Mac-Inegite, F. O. Olowoniyan, and H. O. Chindo. 1996. "Public Health Nutrition: A Comparative Study of the Nutritional Status of Children in Villages in Northen Nigeria Using and not Using Soya Beans." Food and Nutrition Bulletin 17 (1): 1-6. https://doi.org/10.1177/156482659601700109

Sassi, M. 2014. "Economic and Health Determinants of Child Nutritional Status in the Malawian District of Salima." European Journal of Development Research 26 (5): 761-782.https://doi.org/10.1057/ejdr.2013.62

Strauss, J., and D. Thomas. 1998. "Health, Nutrition, and Economic Development." Journal of Economic Literature 36 (2): $766-817$.

Torheim, L. E., I. Barikmo, C. L. Parr, A. Hatløy, F. Ouattara, and A. Oshaug. 2003. "Validation of Food Variety as an Indicator of Diet Quality Assessed with a Food Frequency Questionnaire for Western Mali." European Journal of Clinical Nutrition 57: 1283-1291. https://doi.org/10.1038/sj.ejcn.1601686

Vidmar, S. I., T. J. Cole, and H. Pan. 2016. "Standardizing Anthropometric Measures in Children and Adolescents with Functions for Egen: Update." Stata Journal 13 (2): 366-378. https://doi.org/10.1177/1536867X1301300211

Webb, P., and B. L. Rogers. 2003. Addressing the "In" in Food Security. Occasional Paper 1. Washington, DC: United States Agency for International Development.

Wolfe, W. S., and E. A. Frongillo. 2001. "Building Household Food-security Measurement Tools from the Ground Up." Food and Nutrition Bulletin 22 (1): 5-12. https://doi.org/10.1177/156482650102200102

WHO (World Health Organization). 2006. WHO Child Growth Standards: Length/height-for-age, Weight-for-age, Weight-for-length, Weight-for-height and Body Mass Index-for-age: Methods and Development. Geneva.

2017. Nutrition in the WHO African Region. Brazzaville. 


\section{ANNEX}

\section{Table A 1. Independent variables}

Variable Definition

\section{Child characteristics}

Female

1 if female; 0 otherwise

Age

Age in years

\section{Household characteristics}

Urban

Size

Female head

Head age

Educated mother

\section{Nutrition}

Low food security

Household dietary diversity score (HDDS)

Energy intake

Protein intake

Adult meals per day

Under five meals per day
1 if residing in an urban area; 0 otherwise

Number of people who normally live and eat their meals together in the household

1 if household head is female; 0 otherwise

Age of household head in years

1 if child's mother obtained primary school leaving certificate; 0 otherwise

1 if the household had to resort to any of the following in the week prior to the interview: rely on less preferred and/or less expensive foods, limit portion size at meal-times, reduce number of meals eaten in a day, restrict consumption by adults in order for small children to eat, borrow food, or rely on help from a friend or relative; 0 otherwise

Number of food groups consumed in household in the week prior to the interview. The food groups are (1) cereals, (2) roots and tubers, (3) vegetables, (4) fruits, (5) meat, poultry and offal, (6) effs, (7) fish and seafood, (8) pulses, legumes and nuts, (9) milk and dairy products, (10) oil and fats, (11) sugar and honey, (12) miscellaneous (condiments, coffee, tea, etc.)

Daily per capita energy intake in thousands of kilocalories calculated from a weekly recall of foodstuffs consumed by the household.

Daily per capita animal protein intake in grams calculated from a weekly recall of foodstuffs consumed by the household

Number of meals typically consumed in a day by adult members of the household

Number of meals typically consumed in a day by children in the household aged between 6 months and 5 years

\section{Sanitation}

Clean water

1 if the household has accesses drinking water from an improved source (piped water, protected well, borehole, tanker truck or bowser, bottled water); 0 otherwise

Toilet

1 if household has a toilet; 0 otherwise

\section{Use of health services}

Under-five nutrition program

Under-five clinic
1 if household took part in an under-five nutrition program in the year prior to the interview; 0 otherwise

1 if the child participates in an under-five clinic; 0 otherwise

Source: Authors' compilation. 
Table A 2. Robustness checks (weight-for-height)

\begin{tabular}{|c|c|c|c|c|c|}
\hline Dependent variable & $\begin{array}{c}(1) \\
W H z\end{array}$ & $\begin{array}{c}(2) \\
\text { WHZe }\end{array}$ & $\begin{array}{c}(3) \\
W H Z\end{array}$ & $\begin{array}{c}(4) \\
W H z\end{array}$ & $\begin{array}{c}(5) \\
\text { Not wasted }\end{array}$ \\
\hline \multicolumn{6}{|l|}{ Child characteristics } \\
\hline \multirow[t]{2}{*}{ Female } & $0.108^{*+*}$ & $0.111^{* * *}$ & $0.108^{*+*}$ & $0.112^{* * *}$ & $0.020^{* *}$ \\
\hline & $(0.037)$ & $(0.037)$ & $(0.037)$ & $(0.037)$ & $(0.008)$ \\
\hline \multirow[t]{2}{*}{ Age } & $0.097^{* * *}$ & $0.099^{* * *}$ & $0.101^{* * *}$ & $0.097^{* * *}$ & $0.015^{* * *}$ \\
\hline & $(0.016)$ & $(0.016)$ & $(0.016)$ & $(0.016)$ & $(0.004)$ \\
\hline
\end{tabular}

\section{Household characteristics}

\begin{tabular}{|c|c|c|c|c|c|}
\hline \multirow[t]{2}{*}{ Urban } & $0.170^{* * *}$ & $0.161^{* *}$ & $0.166^{* *}$ & $0.143^{* *}$ & 0.013 \\
\hline & $(0.064)$ & $(0.065)$ & $(0.067)$ & $(0.066)$ & $(0.012)$ \\
\hline \multirow[t]{2}{*}{ Size } & 0.002 & -0.001 & 0.004 & 0.001 & 0.000 \\
\hline & $(0.012)$ & $(0.012)$ & $(0.012)$ & $(0.012)$ & $(0.002)$ \\
\hline \multirow[t]{2}{*}{ Female head } & 0.042 & 0.043 & 0.038 & 0.038 & 0.008 \\
\hline & $(0.054)$ & $(0.055)$ & $(0.056)$ & $(0.054)$ & $(0.010)$ \\
\hline \multirow[t]{2}{*}{ Head age } & 0.001 & 0.002 & 0.001 & 0.001 & -0.000 \\
\hline & $(0.002)$ & $(0.002)$ & $(0.002)$ & $(0.002)$ & $(0.000)$ \\
\hline \multirow[t]{2}{*}{ Educated mother } & 0.080 & 0.073 & 0.078 & 0.081 & 0.005 \\
\hline & $(0.053)$ & $(0.053)$ & $(0.055)$ & $(0.053)$ & $(0.010)$ \\
\hline \multicolumn{6}{|l|}{ Nutrition } \\
\hline \multirow[t]{2}{*}{ Low food security } & 0.044 & 0.053 & 0.054 & 0.038 & 0.011 \\
\hline & $(0.057)$ & $(0.058)$ & $(0.057)$ & $(0.056)$ & $(0.011)$ \\
\hline \multirow[t]{2}{*}{ Household dietary diversity score (HDDS) } & -0.004 & 0.001 & -0.001 & -0.007 & $0.005^{*}$ \\
\hline & $(0.015)$ & $(0.015)$ & $(0.015)$ & $(0.015)$ & $(0.003)$ \\
\hline \multirow[t]{2}{*}{ Energy intake ('000 kcal/person/day) } & 0.030 & 0.031 & 0.034 & 0.030 & -0.004 \\
\hline & $(0.024)$ & $(0.024)$ & $(0.024)$ & $(0.024)$ & $(0.005)$ \\
\hline \multirow[t]{2}{*}{ Protein intake (g/person/day) } & 0.005 & 0.005 & $0.005^{*}$ & 0.005 & 0.001 \\
\hline & $(0.003)$ & $(0.003)$ & $(0.003)$ & $(0.003)$ & $(0.001)$ \\
\hline \multirow[t]{2}{*}{ Adult meals per day } & 0.052 & 0.050 & 0.080 & 0.056 & 0.001 \\
\hline & $(0.049)$ & $(0.050)$ & $(0.049)$ & $(0.049)$ & $(0.010)$ \\
\hline \multirow[t]{2}{*}{ Under five meals per day } & & & -0.044 & & \\
\hline & & & $(0.029)$ & & \\
\hline \multicolumn{6}{|l|}{ Sanitation } \\
\hline \multirow[t]{2}{*}{ Clean water } & -0.006 & -0.009 & -0.022 & 0.000 & -0.007 \\
\hline & $(0.054)$ & $(0.056)$ & $(0.055)$ & $(0.054)$ & $(0.011)$ \\
\hline Toilet & 0.038 & 0.059 & 0.048 & 0.052 & 0.003 \\
\hline
\end{tabular}




\section{Use of health services}

Under-five nutrition program

$\begin{array}{lllll}-0.197^{*+*} & -0.201^{*+*} & -0.211^{*+*} & -0.192^{*+*} & -0.033^{*+} \\ (0.074) & (0.075) & (0.076) & (0.072) & (0.016)\end{array}$

Under-five clinic

$0.075 \quad 0.065$

0.079

0.073

$-0.001$

(0.053)

(0.056)

(0.054)

(0.052)

(0.010)

\begin{tabular}{lccccc} 
Month of interview fixed effects & NO & NO & NO & YES & 6,277 \\
$\mathbf{N}$ & 6,277 & 6,290 & 6,277 & 0.023 & 0.025 \\
$\mathbf{R}^{2}$ & 0.021 & 0.021 & 0.013 \\
\hline
\end{tabular}

Note: Authors' estimations based on IHS4 data. Model 1 corresponds to model 1 in Table 4 for ease of comparison with the remaining models in this table. WHZe is identical to WHZ but includes extreme values $(<-5$ and $>5)$. Not wasted is the inverse of the wasted dummy to make the interpretation of $+/$ - signs consistent with WHZ models in this table. Standard errors in parentheses. ${ }^{*} p<0.10,{ }^{* \star} p<0.05$, ${ }^{* \star *} p$ $<0.01$. 
Table A 3. Robustness checks (height-for-age)

\begin{tabular}{|c|c|c|c|c|}
\hline Dependent variable & $\begin{array}{c}(1) \\
\text { HAZ }\end{array}$ & $\begin{array}{c}(2) \\
H A Z e\end{array}$ & $\begin{array}{c}(3) \\
H A Z\end{array}$ & $\begin{array}{c}\text { (4) } \\
\text { Not stunted }\end{array}$ \\
\hline \multicolumn{5}{|l|}{ Child characteristics } \\
\hline \multirow[t]{2}{*}{ Female } & $0.122^{* * *}$ & $0.135^{* * *}$ & $0.112^{* * *}$ & $0.041^{* * * *}$ \\
\hline & $(0.041)$ & $(0.042)$ & $(0.042)$ & $(0.014)$ \\
\hline \multirow[t]{2}{*}{ Age } & $-0.254^{* * *}$ & $-0.253^{* * *}$ & $-0.253^{* * *}$ & $-0.047^{* * *}$ \\
\hline & $(0.017)$ & $(0.018)$ & $(0.017)$ & $(0.005)$ \\
\hline
\end{tabular}

\section{Household characteristics}

\begin{tabular}{|c|c|c|c|c|}
\hline \multirow[t]{2}{*}{ Urban } & 0.012 & 0.029 & -0.009 & -0.007 \\
\hline & $(0.077)$ & $(0.077)$ & $(0.077)$ & $(0.021)$ \\
\hline \multirow[t]{2}{*}{ Size } & 0.015 & 0.012 & 0.017 & 0.003 \\
\hline & $(0.015)$ & $(0.016)$ & $(0.016)$ & $(0.005)$ \\
\hline \multirow[t]{2}{*}{ Female head } & 0.020 & 0.010 & 0.018 & 0.010 \\
\hline & $(0.058)$ & $(0.061)$ & $(0.059)$ & $(0.018)$ \\
\hline \multirow[t]{2}{*}{ Head age } & $0.004^{*}$ & $0.004^{*}$ & $0.004^{*}$ & 0.001 \\
\hline & $(0.002)$ & $(0.002)$ & $(0.002)$ & $(0.001)$ \\
\hline \multirow[t]{2}{*}{ Educated mother } & $0.196^{* * *}$ & $0.191^{* * *}$ & $0.192^{* * *}$ & $0.061^{* * *}$ \\
\hline & $(0.054)$ & $(0.056)$ & $(0.055)$ & $(0.018)$ \\
\hline \multicolumn{5}{|l|}{ Nutrition } \\
\hline \multirow[t]{2}{*}{ Low food security } & $-0.202^{* * *}$ & $-0.213^{* * *}$ & $-0.208^{* * *}$ & $-0.045^{* *}$ \\
\hline & $(0.062)$ & $(0.063)$ & $(0.063)$ & $(0.018)$ \\
\hline \multirow[t]{2}{*}{ Household dietary diversity score (HDDS) } & $-0.030^{* *}$ & $-0.033^{* *}$ & $-0.032^{* *}$ & $-0.007^{*}$ \\
\hline & $(0.013)$ & $(0.013)$ & $(0.014)$ & $(0.004)$ \\
\hline \multirow[t]{2}{*}{ Energy intake ('000 kcal/person/day) } & 0.003 & 0.011 & 0.012 & 0.002 \\
\hline & $(0.032)$ & $(0.032)$ & $(0.033)$ & $(0.010)$ \\
\hline \multirow[t]{2}{*}{ Protein intake (g/person/day) } & 0.000 & 0.001 & -0.000 & 0.001 \\
\hline & $(0.004)$ & $(0.004)$ & $(0.004)$ & $(0.001)$ \\
\hline \multirow[t]{2}{*}{ Adult meals per day } & 0.020 & 0.014 & 0.017 & -0.003 \\
\hline & $(0.040)$ & $(0.041)$ & $(0.045)$ & $(0.014)$ \\
\hline \multirow[t]{2}{*}{ Under five meals per day } & & & -0.004 & \\
\hline & & & $(0.031)$ & \\
\hline \multicolumn{5}{|l|}{ Sanitation } \\
\hline \multirow[t]{2}{*}{ Clean water } & $0.172^{*+*}$ & $0.152^{* *}$ & $0.178^{* * *}$ & $0.063^{* * *+}$ \\
\hline & $(0.064)$ & $(0.064)$ & $(0.065)$ & $(0.021)$ \\
\hline Toilet & 0.041 & 0.049 & 0.045 & 0.002 \\
\hline
\end{tabular}




\section{Use of health services}

Under-five nutrition program

$-0.103$

$-0.129$

$-0.121$

$-0.018$

\begin{tabular}{|c|c|c|c|c|}
\hline & $(0.076)$ & $(0.079)$ & $(0.077)$ & $(0.025)$ \\
\hline \multirow[t]{2}{*}{ Under-five clinic } & $-0.212^{* * *}$ & $-0.220^{* * *}$ & $-0.210^{\star * *}$ & $-0.047^{* *}$ \\
\hline & $(0.055)$ & $(0.056)$ & $(0.058)$ & $(0.019)$ \\
\hline $\mathbf{N}$ & 6,280 & 6,295 & 5,957 & 6,280 \\
\hline $\mathbf{R}^{2}$ & 0.065 & 0.059 & 0.065 & 0.024 \\
\hline
\end{tabular}

Note: Authors' estimations based on IHS4 data. Model 1 corresponds to model 2 in Table 4 for ease of comparison with the remaining models in this table. HAZe is identical to HAZ but includes extreme values $(<-5$ and $>5)$. Not stunted is the inverse of the wasted dummy to make the interpretation of $+/$ - signs consistent with HAZ models in this table. Standard errors in parentheses. ${ }^{*} p<0.10,{ }^{* *} p<0.05$, ${ }^{* \star} p$ $<0.01$. 
The Malawi Strategy Support Program (MaSSP) is managed by the International Food Policy Research Institute (IFPRI) and is made financially possible by the generous support of the American people through the United States Agency for International Development (USAID), and by the UK Department for International Development (DFID). This publication has been prepared as an output of MaSSP and has not been independently peer reviewed. Any opinions expressed here belong to the authors and are not necessarily representative of or endorsed by IFPRI, the US or the UK government's official policies.

INTERNATIONAL FOOD POLICY RESEARCH INSTITUTE

A world free of hunger and malnutrition

IFPRI is a CGIAR Research Center

IFPRI Malawi, Area 14 Office, Plot 14/205, Lilongwe, Malawi | Mailing Address: PO Box 31666, Lilongwe 3, Malawi

T +265-1-771-780 | Email: IFPRI-Lilongwe@cgiar.org | http://massp.ifpri.info 